\title{
CAPACITY STRENGTHENING PROGRAM FOR SMALL AND MEDIUM ENTERPRISES (SMES) IN RELIGIOUS TOURISM VILLAGE OF BONGO AT GORONTALO REGENCY
}

\author{
Ismet Sulila \\ "Department of Public Administration, Faculty of Economics, Universitas Negeri Gorontalo, Gorontalo \\ "Corresponding Author: ismet.sulila@gmail.com
}

\begin{abstract}
The program on regional leading product development (program pengembangan produk unggulan daerah, henceforth called as PPPUD) for Karawo- the local Gorontalo's embroidery product- has been carried out to domestic crafters in the Religious Tourism Village of Bongo from 2017 and expected to be completed by 2019. The initial year project focuses on strengthening the business management of the karawo, including strengthening the capacity of human resources and related production facilities. This capacity strengthening program is carried out in collaboration with the Cooperative, Industry, Trade and SMEs Department of Gorontalo regency. This initial year program has brought positive results that are evident in each of the following indicator: 1) the increase of managerial technical capacity of the management and all members of the SMEs groups, 2) all aspects of human resources are fulfilled and strengthened and thus, have brought impact on the quantity and the quality of the product; 3) all production-related facilities are fulfilled, and the office spaces are also furnished hence, have brought positive impact on production and the management activity, these improvement have brought impact on the marketing of the karawo products produced by these SMEs. Based on this initial year's achievements, the focus of the second year would be on strengthening the production, finance, and raw material's aspects of the karawo. Therefore, it is crucial for this community empowerment program through the PPUD program to be carried out into the next year.
\end{abstract}

Keywords: Management, Human Resource, Karawo Production Facilities and Products.

\section{INTRODUCTION}

Karawo is widely known as an embroidery handicraft produced by local people of Gorontalo. The legacy of embroidery craftmanship has been passed down from generation to generation among the Gorontalonese society and has attracted not only Gorontalonese as its user but also people from outside of this region. As a regional leading product, it is expected that this craftmanship skill will always be preserved among the embroiderers and that the embroiderers' capacity in business management, including human resource capacity and the product quality, will increase. Therefore, stakeholders' involvement for improvement are welcome. In relation to this, Universitas Negeri Gorontalo (henceforth called as UNG) is expected to play crucial roles in improving the management and the quality of karawo embroidery. One of them is through implementation of PPPUD program which was implemented in collaboration with the Ministry of Research and Technology and Higher Education of the Republic of Indonesia.

Karawo embroidery activity is common among Gorontalonese, including in Bongo village of Batudaa pantai sub-district, in the regency of Gorontalo, Gorontalo Province. Out of several karawo embroiderers groups in this area, there were two groups of embroiderers selected to be assisted through PPPUD program. Those two groups were the Annisa Karawo embroiderers group and Nirwana Karawo embroiderers group. These two groups were selected due to the following considerations: 1) the members of these two SMEs group have been working hard to develop their business despite their limitations; 2 ) their products were less developed; 3 ) these two groups were found lacking in management and in quality of the product; 4) the groups' members were willing and open to develop their SME groups' product to meet the market demand.

Based on several field visits and field analysis, it was concluded that in general, the groups' problems were: 1) raw material; 2) production; 3) process; 4) products; 5) distribution; 6) management; 7) marketing; 8) human resources; 9) facilities; and 10) finances. Therefore, due to problems identified above, PPPUD intervention program were to be 
implemented for three consecutive years, from 2017 to 2019 by selecting and determining the priority problems to be addressed in each year. In 2017 program, three issues were targeted and solved: management, human resource, and facilities. The solutions for these three issues in 2017 were as follow: 1) management. Management is the key issue in business. SME will only able to succeed and progressed if there is management's commitment and consistency in the business. Therefore, to solve the management problem, reconstruction of all current conventional management practices (planning, organizing, actuating, and controlling) were the solution. Planning function: SME groups need to know what items should be planned in a business, how to make a business plan for a period of business year, how to prioritize in planning, and how to create a realistic planning; including how to make resource planning, which involves human resource and financial resources, tools, raw material, and market access; how to develop new karawo motifs that are only available in the religious tourism village of Bubohu. Organizing function: the SMEs groups should know how to determine the needed resources, how to categorize those resources, and how to maximize those resources. Actuating function: the SMEs groups can operationalize each business plan step by step to reach the realistic target that was previously determined by adjusting as much as possible to the current market condition. Controlling function: the SMEs groups should ensure that each stage of the business plan is implemented effectively, and accurately identify and act on each problem or appropriately react to the change of environment. Outcome: the SMEs groups understand the management functions and apply those functions in accurately and measurable in their business practices.

2) Human resource. Human resource is the most important aspect in business. A success or failure of a business is determined by its human resource. Thus, the solution for human resource problem in these two SMEs groups was found. Solution: conduct manpower mapping, which focused on two things, administrative management and the workers/karawo embroiders. This mapping was intended to determine types of manpower needed in this business. Previously, the administrative people did not know what aspects of business that they should work on and prepared for in managing the karawo business. The administrative aspect of business in Annisa SME group was managed by the owner herself. Therefore, the improvement was done by recruiting one administrative staff who will prepare all business administration. Whereas, for production side of the business, at least there are 25 members of the group who are willing to work on producing the karawo and have capacity to make several motifs of karawo such as, walima motif, fish motif, coconut tree motif, and mosque motif in six types of karawo products as their leading products. Outcome: human resource as the key factor for the success of the SMEs groups' business, both in management aspect and production aspect of karawo production in religious tourism village of Bongo are organized.

3) facilities. in addition to the management and human resource aspects, the third priority in 2017 activity was facilities. sufficient production facilities also determined the success of karawo business as the leading product of Bongo village. Solution: identification of facilities needed in karawo business, both the administrative facilities or production and marketing facilities. Field verification revealed that the needed facilities are: 1) representative office space, 2) two sets of office furniture, 3 ) fan for the office space, 4) blinds, 5) computer and printer, 6) internet access, 7) product showcase, 8) leaflet/brochure, 9) board to display management structure, 10) photo/model to display various usage of the karawo product as the leading product from Bongo. In addition to these, the production facilities that should be fulfilled are: 1) preparation of workshop space in the group's activity center, 2) additional embroider needles, 3) additional frame to make karawo, 4) additional sewing machine to sew the karawo and batik combination, and to create motifs of karawo such as walima, fish, coconut tree, and mosque's motifs, 5) overlock machine, 6) overcast machine, 7) packaging machine, and 8) other supporting equipment. Outcome: basic facilities needed for administration and production were fulfilled. These facilities would further be used to produce karawo with different motifs, which would be marketed in the province.

Based on priority issues identified in these two SMEs group, three business aspects issues were selected to be improved in the initial year of program implementation: 1) strengthening of the management capacity, 2) human resource management, and 3) facilities improvement. These improvement activities were appropriate and needed by the embroiderers groups in Bongo village as this village is the center of traditional karawo production. Their products have been marketed to fulfill the domestic market demand and outside the island demand. However, their businesses were conventionally implemented and the management principles as well as the quality were not yet as expected. Hence, from the aspects of financial, production, and marketing management, these two groups of SMEs are currently facing problems in managing their businesses. Implementation of management principles and fulfilling the standard market demand are urgent for these two groups to meet the demand of boutiques from all over Gorontalo 
and its surrounding area.

The main obstacle was the embroiderers' group understanding on aspects of management; planning, resources allocation, understanding the market trend, determining the production and cost, product distribution, etc. In addition, the ultimate target in this stage was that the groups will be able to have outlets/boutiques as their product distribution/marketing channel. Thus, the team of community outreach from UNG had implemented the PPPUD program to help assist these two groups in meeting the main challenges in karawo business.

Knowledge transfer along with hands on practices which involved lecturers, students, and local community, especially the members of the group as the focus of activities were implemented in this outreach program. To maximize the output of this program, stakeholders' involvements were also facilitated through resources available in this village, which consist of meeting venue, workshop space, library, and learning center, as well as room and facilities to practice karawo embroidery that meet the demand of the market in Gorontalo and its surrounding areas.

Mubarak (2010) wrote that community empowerment could be defined as efforts to restore or improve certain community's ability to act based on their prestige and dignity in implementing their rights and responsibilities as part of the community. Meanwhile, Shuckmith (2013) stated that bottom up approach to develop village is based on assumption that local's specific resources, nature, human, and culture hold a key to its development. The success of an empowerment, according to Wilson (1996) depended on seven stages of community empowerment cycles in which the first cycle is the community willingness to change for the better. The second stage is that community is expected to be able to overcome the intrinsic obstacles from themselves and their community. The third stage is that the community is expected to have additional freedom and have responsibility to develop themselves and their community. The fourth stage is the efforts to develop wider role and wider boundary of responsibility, this is also related with the interest and motivation to do the job better. The fifth stage is that the real result of the empowerment efforts is starting to be evident, where there is an improvement of sense of ownership to create better performance output. The sixth stage is that there is a change of behavior and the impression on oneself, where success in performance improvement will be to improve psychological condition. The seventh stage is that community who have successfully empower themselves felt challenged to work harder in order to yield a better result. The success of a community outreach program is also due to the role of partnering agencies to play their main roles.

\section{MATERIALS AND METHOD}

The steps that were taken for each focus of activities are as follow: 1) Management: improved all aspects of management, from planning to evaluation of business performance in monthly period. All management functions were implemented in detail and comprehensively by taking into consideration the internal and external aspects. In addition, group organizing and assistance were also conducted by analyzing the management and analyzing the business practices in these two targeted SMEs group. 2 ) human resource: conducted comprehensive study on the human resources needed to implement various aspects of the business, from the office space to production, and product marketing. Further, the recruitment and selection, and resource orientation, assistance/trainings were conducted to accommodate the needs so they could effectively and efficiently work. The human resources were also periodically evaluated, especially in marketing and production aspects. The production aspect was evaluated to ensure the standardization of karawo product as the leading product that are unique and can be traced to Bongo village. Whereas, the marketing aspect was evaluated to ensure the continuity of the marketing and distribution of karawo product to meet the standard that had been set. 3) Facilities: the fulfilment of facilities such as, showroom, computer, internet network, showcase, sewing machine, overcast machine and other supporting facilities.

In addition to the direct assistance method as mentioned above, this community outreach program also applied the group learning where the groups learned and practiced how to make the package and the label as well as learned how to sell the products. These learnings were accompanied by hands on practices that were conducted together with the students.

On the other hand, to ensure the sustainability of this program in the future, commitment and willingness are needed. Program sustainability is determined by the work commitment of the groups, village government and implementing team in cooperation with local youth group as the organizer to make this program sustainable. Students' involvement in this program was to map the potentials and the problems that may arise and to assist in finding the solutions and their alternatives. Production technology assistance, packaging, and marketing were efforts to increase the efficiency and efficacy of karawo business management process. These assistances were expected to improve the performance of karawo production and improve the management and standardization of karawo product quality 
produced by the target groups. The marketing process was also assisted by the university students, hence, following the completion of the program, the market would be sustainable and expected to be followed by the increase of sales. Currently, there are several shops where the karawo produced by these two groups are sold, such as, the Toko Sumber Karawo and the Pusat Ole-ole Gorontalo.

\section{FINDINGS AND DISCUSSION}

In addition to hands on practices guided by the team and students' involvement, other technical assistances were also given to both teams. These technical assistances were focused on several themes such as:

1. First topic: Karawo potentials and various problems experienced by the embroiderers in Bongo. These two SMEs group were groups founded by the embroiderers themselves. For these embroiderers, embroidering karawo is a skill that has been passed down for generations. The growing numbers of embroiderers and the increase of demands for variety of karawo products are potentials for the embroiderers. Nevertheless, these potentials have not been maximally explored. Therefore, through this PPPUD program, the karawo potentials can be maximized and can yield maximum benefit to increase the welfare of the SMEs groups and the community in Bongo village. The karawo can also be developed as the income potential for Bongo village due to its distinctive motifs that cannot be found anywhere else, such as the fish, coconut tree, and the walimah motifs.

2. Second topic: synergy of government and higher education institution and community in empowering and increasing the welfare of the karawo embroiderers groups. This topic emphasized the importance of three higher education services, especially community outreach. As an institution that develops knowledge and technology, higher education institution's role is needed in developing the region's leading product. PPPUD is one of the mandates from the Ministry of Research and Technology and Higher Education of the Republic of Indonesia through its implementing team in Universitas Negeri Gorontalo which aimed at developing the potential local products made by the SMEs in local and national scales. Through this program, it is expected that partnership between higher education institutions and SMEs groups will be established. In addition, cooperation with related stakeholders such as: national board of local handicrafts (DEKRANASDA), Industrial and Trades Agency in Regency and Provincial level, and other relevant stakeholders are expected to be established through this program.
3. Third topic: business administration and embroiderers' organizational revitalization. This topic emphasized the importance of business administration and revitalization of the two SMEs organizations. These two SMEs had to have clear planning, smooth operation, and effective marketing. In order to achieve these, willingness to learn to tidy up and commitment to act on practicing the business aspects professionally is needed. In addition, in these aspects the business problems' mapping skill, analysis, and decision-making to create concrete solutions for the problems in hand are also needed.

4. Fourth topic: Legal aspect in business and the importance of intellectual rights and the mechanism to apply for intellectual rights for SME. This topic was intended to give understanding for the targeted group on the risk which may arise in business practices, writing up the sales/purchase contract, legal aspect in capital, and also the possibility to apply for intellectual rights for the motifs that they have invented. This topic also opened up an opportunity to discuss and to consult legal actions that might be taken in protecting the SME groups. Legal aspect education had given positive impact for the groups in considering their future business decisionmaking. It was to be noted also that copyrights protect the rights, not the embodiment of the rights Muliani, 2007).

5. Fifth topic: business management, market mapping and sustainable partnership planning in absorption of karawo product in Gorontalo province. This topic made the members of the group understand on the importance of business management aspect, local and national market mapping to win the market competition. The targeted groups were also given understanding on how to design mutual partnership with the third parties or other parties. Management issues were important due to the definition of management itself as proposed by Hasibuan (2011) that management is a science and art to effectively and efficiently manage the process of utilization of human resources and other resources to achieve certain objectives.

6. Sixth topic: Theory and Practices on how to design a feasibility study of karawo business for embroiderers group. In this topic the members of targeted groups were given knowledge and hands on experience on how to develop realistic work plan based on the current internal and external condition of the SME and how to make a long-term business plan. This experience had ensured the members of the groups on the prospect of their business and how to plan their karawo business realistically and systematically. In relation to business feasibility, Nurmalina 
(2009) mentioned that business feasibility is an analysis on whether an investment activity would yield benefit if it is implemented. Meanwhile, Umar (2001) proposed that a feasibility study is a study on whether an investment is feasible or not to be implemented. The result of this feasibility study is an estimation of benefit that may be received when a business is operated. Success estimation may be interpreted differently for the business purposes.

7. Seventh topic. Innovation practice for karawo product. This innovation practice was implemented by one of the partners who has knowledge and experience on karawo. All the participants participated in this innovation workshop and practiced the innovation to create new products made from karawo to be marketed locally and nationally.

The result of this karawo technical assistance in Bongo village had given experience and capacity strengthening for the group members on the karawo potentials as a unique embroidery product from Gorontalo to be marketed in wider market. In addition, the technical assistances were also given to improve their knowledge on how to manage the karawo business. The groups were also taught the legal aspect of the business. This was to give legal certainty toward their business as well as shared knowledge on various risks that may arise in business. In addition, the targeted groups were also taught how to develop partnership with other parties, market design etc. These technical assistances were also followed by theory and practices on how to develop a business plan for the SMEs groups, where all members of the groups participated.

\section{CONCLUSION}

Through PPPUD program in 2017 there have been many empirical evidence and experiences gained by both the lecturers team as the implementers, students, and especially the targeted SMEs. Some of the benefits of yield from this first-year program were:

1) Students were able to put their theory into practice together with the karawo embroiderers groups in religious tourism village of Bonho. The positive and productive attitude of the students, the embroiderers group members, and community in general was one of the impact of this program. The students were starting to use to behave in caring ways, full of empathy toward the social problems around them, especially in the context of karawo embroiderers as the unique product from Gorontalo.

2) The synergy between the embroiderers group and the karawo consumers in Gorontalo area. The local government had also helped in increasing their community empowerment programs through karawo embroiderers group.

3) This activity was a contribution of higher education institution and the implementers' team in sharing their knowledge to contribute toward solving the problems faced by the targeted groups.

Based on the implementation and the result of this initial year program, the implementing team proposed several things below:

1) The 2018 PPPUD program has to be implemented where the focus of activities are programs to continue to address the priority issues as planned.

2) PPPUD program to be continued in the future considering its significant contribution and considering this program has also managed to establish synergy among implementing team, students, targeted community groups, higher education institution, and local government.

3) It is recommended that by the end of the PPUD 2017-2019 program, this activity can be scaled up to Development of Products for Exports program (Program Pengembangan Produk Ekspor/PPE) or through Regional Partnership Program (Pengembangan Kerjasama antar Wilayah/PKW) for it to sustainably strengthen the karawo potentials to be exported from the religious tourism village of Bubohu, Batudaa pantai sub-district, Gorontalo regency.

\section{ACKNOWLEDGEMENT}

We would like to thank the following parties for the success implementation of this initial year of PPUD 2017 program: 1) Directorate General of Community Outreach of the Ministry of Research and Technology and Higher Education of the Republic of Indonesia., 2)Research and Community Outreach Institute of the Universitas Negeri Gorontalo, 3) Government of Gorontalo Regency, Sub-District of Batudaa Pantai and Government of Bongo village, 4) Nirwana embroiderers group and Annisa embroiderers group, 5) implementing team and the students who have participated in this firstyear program. The result of this first year program will be the basis for the implementation of 2018 program which will be focused on: 1) finance, 2) production, 3) raw material, 4) process. Whereas the final program (2019) will be focused on: 1) product, 2) marketing, 3) distribution. We have a high expectation for this community outreach program to be continued in the future.

\section{REFERENCES}

Hasibuan, Malayu SP, 2011, Manajemen Dasar, Pengertian dpan Masalah 
Mubarak, Z, 2010, Evaluasi Pemberdayaan Masyarakat Dari Proses Pengembangan Kapasitas Program PNPM Mandiri Perkotaan di Desa Sastrodirjan Kabupaten Lamongan, Tesis, Program Studi Magister Teknik Pemcberdayaan Wilayah dan Kota

Muliani, Anastasia Resti, 2007, Perlindungan Hukum Hak Kekayaan Intelektual Bagi Usaha Kecil di Bidang Industri Kerajianan di Wilayah Kabupaten Bantul

Nurmalina R, Sarianti T, Karyadi A, 2009, Studi

\section{DOCUMENTATIONS}

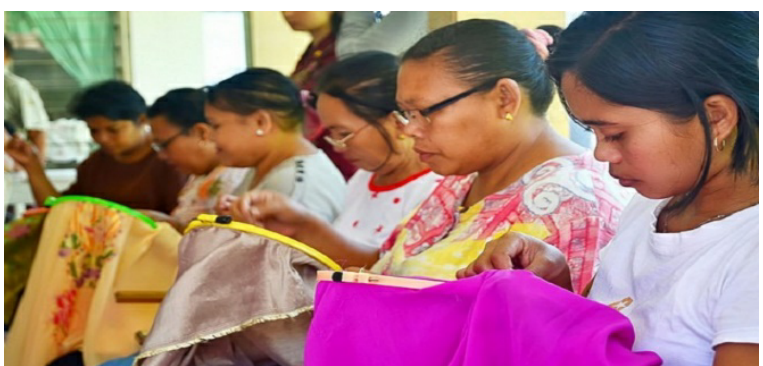

Figure 1: Karawo Embroidery Process

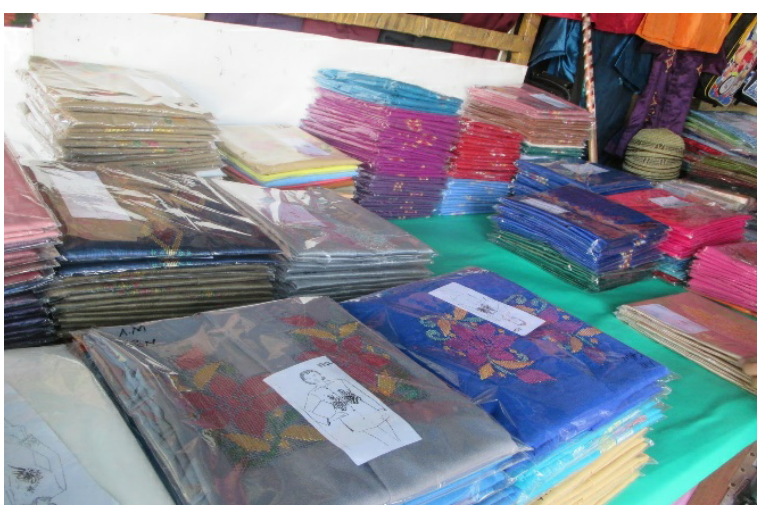

Figure 3. Various Karawo Products
Kelayakan Bisnis, Departemen Agribisnis Fakultas Ekonomi dan Manajamen Institut Pertanian Bogor

Umar, Husein, 2001, Study Kelayakan Bisnis/business feasibility study, Edisi 3 Revisi

Wilson, Terry, 1996, The Empowerment Mannual, London, Grower Publishing Company

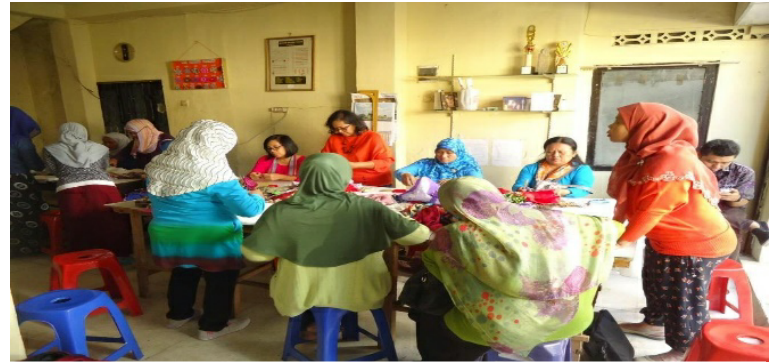

Figure 2. Karawo Embroiderers Activity

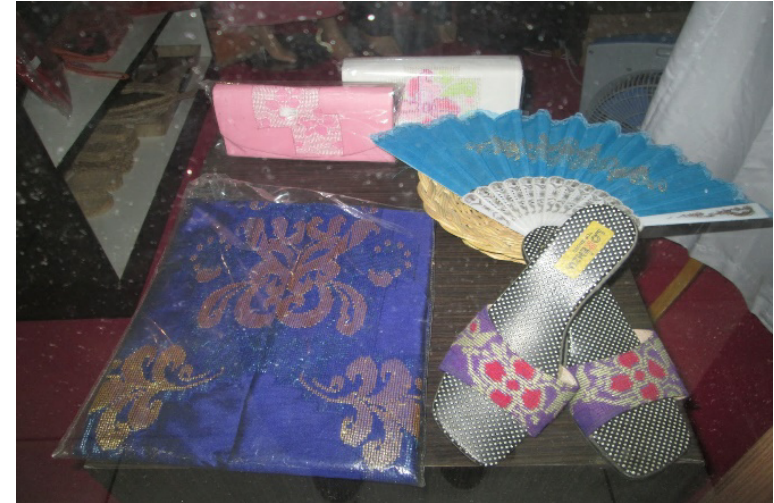

Figure 4. Karawo Products Made by the SMES 